\title{
Electronic Participation through Social Media
}

\author{
Ayman Alarabiat \\ Department of Information Systems \\ University of Minho \\ Guimarães, Portugal \\ id5663@alunos.uminho.pt
}

\author{
Delfina Sá Soares \\ Department of Information Systems \\ University of Minho \\ Guimarães, Portugal \\ dss@dsi.uminho.pt
}

\begin{abstract}
It is widely acknowledge that many of e-Participation initiatives often attract wider audience and face serious limited citizens' involvement. The use of social media has been seen as a hope to remedy such limitation. However, despite the recently adoption of social media the lack of citizens' involvement in e-Participation initiatives still remains. This ongoing research paper aims at producing a general overview of e-Participation through social media.

So far, the latest research works on such topic have been predominantly focused on a political context of e-Participation, where politicians-citizens interactions and activities are the central interest of the studies. Little existing studies investigate eParticipation in its own right in government context. The findings also reveal that the majority of e-Participation through social media initiatives are more informative than interactive, since few initiatives have been found that aim to considerably enhance citizen participation in policy decision making.
\end{abstract}

\section{CCS Concepts}

- Information systems $\rightarrow$ Information systems applications - Information systems $\rightarrow$ Social networking sites $\bullet$ Applied computing $\rightarrow$ E-government.

\section{Keywords}

"E-Participation", "Social media", "Literature review", "EGovernment".

\section{INTRODUCTION}

Research on the use of information and communication technology (ICT), for the purpose of facilitating greater citizen participation in policy decision making process (e-Participation) [1], has witnessed an explosive growth over the last few years [2]-[4]. In practice, the e-Participation initiatives, except in few cases, have not been as successful as initially anticipated, largely due to the lack of citizen involvement [2], [5]-[8]. The majority of the projects have not achieved their intended aims toward creating actual interaction with citizens, and few have attained tangible citizens' influences into policy making process [6], [7], [9], [10]. To overcome such challenge, policy makers - politicians and governments - have been encouraged to go where citizens are, rather than expecting citizens to move from their actual online location [5], [11]. Social media technology has enabled virtual

Permission to make digital or hard copies of all or part of this work for personal or classroom use is granted without fee provided that copies are not made or distributed for profit or commercial advantage and that copies bear this notice and the full citation on the first page. To copy otherwise, or republish, to post on servers or to redistribute to lists, requires prior specific permission and/or a fee.

ICEGOV2016, March 1 - 3 2016, Montevideo, Uruguay

Copyright is held by the owner/author(s). Publication rights licensed to ACM. ACM 978-1-60558-611-3/14/10...\$15.00

DOI: http://dx.doi.org/10.1145/12345.67890 collaborative environments through providing a new way of communication for enriching policy makers, particularly the governments, to interact with citizen and encouraging them to participate in decision making processes [9], [11]-[13]. In due of lower technical "know-how" of social media technology comparing with previous generations of ICT [14], such platforms have shown more advantages compared to the traditional "physical"government e-Participation or e-consultation websites [15]. However, despite such huge attempts, the challenges of eParticipation initiatives to attract and engage more citizens still remains [16]-[18]. In thus, the overall objective of this paper is to assess this theme in e-Participation area of research.

Since the initiatives concerning e-Participation through social media are expected to grow, it seems relevant to address such new topic [2], [4], [9], [11]. At the best of our knowledge, there have not been so far wider significant attempts at reviewing the use of social media in e-Participation. In this sense, this study contributes towards building a good understanding of how eParticipation through social media phenomenon has been understood, implemented and investigated, thus providing a valuable overview for researchers in e-Participation field. To do this, the study analyzes a set of relevant studies that actually investigate e-Participation (and then social media) rather than those which merely citing or mention it.

The remainder of this paper is structured as follows. Section 2 explains the methodology adopted to carry out the research. Section 3 reports major findings on e-Participation through social media. Section 4 presents further discussion of our results. Finally, Section 5 concludes the paper.

\section{RESEARCH METHODOLOGY}

The methodology used to organize the literature review process comprised two steps. Step I - Data Collection - aimed at defining the scope of the data collection process, by selecting the scientific databases and by identifying the keywords for the search. Step II Data Selection - aimed at selecting the most relevant papers within the scoping of our research purpose. The two steps are briefly explained below.

\subsection{Data Collection}

Given the lack of a specific set of key publication venues on eParticipation, it would be hard to select a limited number of major journals as primary source of publications in e-Participation [3]. Therefore, following previous literature review works on eParticipation [2], [3], [19], we decided to base our search on Scopus, ISI-Web of Science, and EBSCO Host data base indexes. The search was conducted for the years 2009-2015 using various queries. The first keyword in the queries was "E-Participation" or "Electronic Participation". The second keyword was "social media", and its different notations "Social Network" and "Web 
2.0". The sample resulted in 97 candidate papers (61 in Scopus, 25 ISI-Web of Science, and 11 in EBSCO Host).

\subsection{Data Selection}

The 97 candidate papers found had to meet two major criteria's to be further used. First, the paper should address e-Participation as a central subject or at least given considerable attention to eParticipation as an essential theme of discussion. Second, the paper should also focus on or combine e-Participation with social media topic. Titles and abstracts of the 97 retrieved papers were scanned to check these two criteria. To increase the chances of finding relevant studies, we also conducted forward citation search, seeking for relevant studies that cited one of the most fundamental e-Participation publications (also called citation tracking) [20]. Consequently, this process yielded 42 of 97 papers that given considerable attentions for both topics.

\section{RESULTS}

While social media has a potential to enhance citizen participation at different stages of the policy making process [2], [4], [6], [11], it is rarely approached in e-Participation studies [21]. Clearly, there is still scant research on e-Participation and social media [2], [4]. Even considering that we have identified a fair number of references ( 25 studies) that caught both e-Participation and social media in the same study, the majority of them are limited to an exclusive group of researchers and covered covered nearly the same contributions by the same group of authors. For instance, some authors participate in 3 studies [22]-[24], 2 studies [25], [26], [8], [27], or even 5 studies such as [11], [16], [18], [28], [29].

The review of e-Participation through social media could be classified into three major results as follows:

1) Interaction - The politicians-citizens interactions has dominated scholars' attention and certain political issues and activities (e.g. e-campaigns and e-voting) are the main focal points of e-Participation through social media studies [16], [17], [23], [24], [29]-[33]. The prediction of election results is another issue that has gained researchers attention [23], [24], [26]. The review shows continuous attempts to evaluate the influence of social media in political campaigns. Some scholars propose predicting instruments for future voting based on the examination of political candidates engagement on social media frequencies [23], [24]. These findings seem quite surprising, since e-Participation is a process that contains other actors (e.g. government institutions and citizens) as well as other important activities (e.g. econsultation and online decision making) [2], [3]. Considering these results, e-Participation studies through social media seem biased around political processes, similar to the research conducted in the whole filed [4], [19].

2) Aim - In practice, the mainstream of e-Participation through social media initiatives was performed to reinforce politicians' position rather than to conduct dialogue with citizens [29]. Politicians actually use social media platforms as a venue to express themselves, spread their information, and announce their activities in order to raise their image and to gain more constituent votes during election time [26], [29], [33].

These implementations reflect a significant gap between the promise (what politicians' state) and how they actually behave (what they really do). Politicians state that they use e-Participation through social media for engaging in dialogue with citizens, meanwhile they actually post statements [29]. For some, this indicates a failure to understand that e-Participation, likewise social media, goes far beyond offering additional opportunities to disseminate information for only election purposes [29], [32].

3) Integration - More recent efforts have been made towards supporting government's e-Participation initiatives that aim at improving citizen's participation in government policy making processes [18], [27], [28]. However, they are still few of such efforts comparing with the increasing of e-Participation research over the last few years. An analyses of e-Participation studies reveal a lack of integration of e-Participation through social media strategy into government institutions' work, communication strategy, and decision-making processes [18], [27], [28], [34]. Current e-Participation research has little information of how eParticipation forms can be integrated with social media tools and services for policy decision making process (since social media offers online discussion platform, chat and online surveys and polls possibilities).

\section{DISCUSSION}

There are three major criticisms to be made of the existing literature on e-Participation through social media.

First, typical e-Participation through social media research is more driven towards political system activities (e.g., e-voting, e-campaign), which might nearly address similar topics and discuss same ideas as the ones presented in the field of eDemocracy. Such e-Participation initiatives have been mainly addressed by politicians to seek potential vote-gaining during election time. Some practical cases, as those founded through Italian [35], Norwegian, and Swedish elections [36], have found that politicians simply stopped, or lose interest in, using social media after the election day. Hence, this view of e-Participation can be seen as communication, rather than truly participation [37]. In this sense, the way for enhancing citizen participation in the process of decision making, should not only being seen through politicians' campaign or voting in election. The majority of eParticipation studies rarely capture and investigate such initiatives sponsored by government, which seems that the e-Participation field community is reluctant to move forward to the eGovernment context.

Second, most e-Participation research founded in eGovernment research context has not enough addressed eParticipation as a central theme of discussion, but instead, the concept has been superficially examined along with other government concerns for a general coverage (e.g., openness, transparency, and accountability). Although, e-Participation might have impact on public policy objectives and principles such as openness, transparency, and accountability, e-Participation should not be looked only for that reason [10]. Besides that, eParticipation use for openness, accountability, and transparency does not necessarily means truly participation [7], [9], [34], [38]. For instance, an analysis of 75 European municipalities websites came to concluded that employing social media has positive forward impact for enhancing governments transparency but not e-Participation [38]. Citizen e-Participation should be seen as a space seeking for active citizens' involvement to influence and to achieve desirable status, rather than only communication [39]. Researchers should be aware of such differences through advance e-Participation studies. 
Third, comparing e-Participation through social media research within both fields of e-Participation and e-Government shows a weak intersection and remains largely unconnected. It seems that e-Participation scholars and their counterpart from eGovernment field rarely built on each other works. Researchers in each field show little interest in transferring previous findings and knowledge from each other.

In practice, using social media in an effective way requires more than simply creating an account to have a social media presence. Instead, many important factors should carefully be considered. One of such factors is to address citizens' needs rather than just to increase the number of followers [16], and to reflect citizen's feedback through social media in governmental change [12], [18], [40], [41]. Although, the studies analyzed make evident that many of such initiatives are being performed under the absence of real policy makers commitment and believes [12], [18], [31], [40], [41].

From the supply side, conversely to social media's strength, governments have been slow to adopt it [14]. In fact, the uptake of social media among European national governments is still slow [42]. Nevertheless, as social media holds an enormous potential for policy makers to engage citizens, the adoption of these tools confronts a series of challenges. For instance, the politicians have little knowledge and skills on utilizing and managing social media to support their interaction with citizens, which in many cases prevent from taken full advantage of these tools [33]. A survey of 850 United States government managers in 500 cities reveald a high shortage of their knolwedge and experince on how social media could be designed to support their interactions with citizens [40].

The above mentioned issues afford numerous opportunities to conduct research. For example, from the supply side, there is a lack of research on government agencies' ability to manage such initiatives and how to integrate social media with their mission [40] as well with their communication strategies [28]. Research is also necessary to decide what is the suitable type of government content for distribution through social media channels [40]. From the demand side, citizens' motivations, needs, requirements, and expectations to participate need to be significantly explored. The resistance for such interaction, either from government officials' and politicians' perspectives [12], [16], [28], [40] or from citizens' perspective [9], [11], [13], [29], requires also a deeper understanding and study from researchers.

\section{CONCLUSION}

E-Participation through social media initiatives have achieved little success on attracting greater citizens' engagement. Most of such initiatives have been heavily performed as one way communication method, mainly for broadcasting information rather than for enabling citizens to be actually involved in decision-making processes. It seems that such initiatives are still been implemented through outdated management policies and procedures, which earlier failed to touch citizen's needs and requirements [12], [18], [40]. In other words, they seem to be replicating the way e-Participation through official websites had been used earlier - mostly for pushing information with a little real effort to promote citizen's engagement. Our argument, in alignment with the doubts raised by some other scholars, is that many e-Participation initiatives seem to be implemented more for "calming" citizens, by transmitting them a deceptive sense of participation, rather than for making them truly influential [43].
In ending, if e-Participation through social media is used just for dissemination information, probably, we don't expect that such approach would easily attract more citizens, and attain their great involvement.

\section{ACKNOWLEDGMENTS}

The authors would like to thank the two anonymous reviewers for their comments. The authors are very grateful to Dr. Elsa Estevez for her generous constructive review that greatly contributed to improving the final version of the paper. This work has been supported by Portuguese FCT - Foundation for Science and Technology within the Project Scope UID /CEC / 00319/2013.

\section{REFERENCES}

[1] A. Macintosh, "Characterizing e-participation in policymaking," presented at the System Sciences, 2004. Proceedings of the 37th Annual Hawaii International Conference on, 2004, p. 10-pp.

[2] R. Medaglia, "eParticipation research: Moving characterization forward (2006-2011)," Government Information Quarterly, vol. 29, no. 3, pp. 346-360, Jul. 2012.

[3] Ø. Sæbø, J. Rose, and L. S. Flak, "The shape of eParticipation: Characterizing an emerging research area," Government information quarterly, vol. 25, no. 3, pp. 400428, 2008.

[4] I. Susha and Å. Grönlund, "eParticipation research: Systematizing the field," Government Information Quarterly, vol. 29, no. 3, pp. 373 - 382, 2012.

[5] Y. Charalabidis and E. Loukis, "Transforming Government Agencies' Approach to E Participation through Efficient Exploitation of Social Media.," 2011.

[6] A. Macintosh, S. Coleman, and A. Schneeberger, "eParticipation: The research gaps," Lecture Notes in Computer Science (including subseries Lecture Notes in Artificial Intelligence and Lecture Notes in Bioinformatics), vol. 5694 LNCS, pp. 1-11, 2009.

[7] Ø. Sæbø, L. S. Flak, and M. K. Sein, "Understanding the dynamics in e-Participation initiatives: Looking through the genre and stakeholder lenses," Government Information Quarterly, vol. 28, no. 3, pp. 416-425, Jul. 2011.

[8] P. Panagiotopoulos, S. Sams, T. Elliman, and G. Fitzgerald, "Do social networking groups support online petitions?," Transforming Government: People, Process and Policy, vol. 5, no. 1, pp. 20-31, 2011.

[9] E. Sanchez-Nielsen and D. Lee, "eParticipation in Practice in Europe: The Case of" Puzzled by Policy: Helping You Be Part of EU," presented at the System Sciences (HICSS), 2013 46th Hawaii International Conference on, 2013, pp. 1870-1879.

[10] E. Tambouris, A. Macintosh, E. Dalakiouridou, S. Smith, E. Panopoulou, K. Tarabanis, and J. Millard, "eParticipation in Europe: Current State and Practical," EGovernment Success around the World: Cases, Empirical Studies, and Practical Recommendations:, p. 341, 2013.

[11] Ø. Sæbø, J. Rose, and T. Nyvang, "The Role of Social Networking Services in eParticipation," in Electronic Participation, vol. 5694, A. Macintosh and E. Tambouris, Eds. Springer Berlin Heidelberg, 2009, pp. 46-55. 
[12] J. C. Bertot, P. T. Jaeger, S. Munson, and T. Glaisyer, "Social media technology and government transparency," Computer, no. 11, pp. 53-59, 2010.

[13] R. Sandoval-Almazan and J. R. Gil-Garcia, "Are government internet portals evolving towards more interaction, participation, and collaboration? Revisiting the rhetoric of e-government among municipalities," Government Information Quarterly, vol. 29, Supplement 1, pp. S72 - S81, 2012.

[14] I. Mergel, Social media in the public sector: A guide to participation, collaboration and transparency in the networked world. John Wiley \& Sons, 2012.

[15] E. Ferro, E. N. Loukis, Y. Charalabidis, and M. Osella, "Evaluating Advanced Forms of Social Media Use in Government," 2013.

[16] E. Rustad and O. Sæbø, "How, why and with whom do local politicians engage on facebook?," Lecture Notes in Computer Science (including subseries Lecture Notes in Artificial Intelligence and Lecture Notes in Bioinformatics), vol. 8075 LNCS, pp. 69-79, 2013.

[17] W. Wakabi and Å. Grönlund, "When SNS use Doesn't Trigger e-Participation: Case Study of an African Authoritarian Regime," International Journal of E-Politics (IJEP), vol. 6, no. 2, pp. 14-29, 2015.

[18] F. Wahid and Ø. Sæbø, "Affordances and Effects of Promoting eParticipation Through Social Media," in Electronic Participation, vol. 9249, E. Tambouris, P. Panagiotopoulos, Ø. Sæbø, K. Tarabanis, M. A. Wimmer, M. Milano, and T. Pardo, Eds. Springer International Publishing, 2015, pp. 3-14.

[19] C. Sanford and J. Rose, "Characterizing eParticipation," International Journal of Information Management, vol. 27, no. 6, pp. 406-421, Dec. 2007.

[20] J. Webster and R. T. Watson, "Analyzing the past to prepare for the future: Writing a literature review," Management Information Systems Quarterly, vol. 26, no. 2, p. 3, 2002.

[21] S. Bohman, "Information Technology in eParticipation Research: A Word Frequency Analysis," in Electronic Participation, Springer, 2014, pp. 78-89.

[22] R. Effing, J. van Hillegersberg, and T. Huibers, "Social media and political participation: are Facebook, Twitter and YouTube democratizing our political systems?," in Electronic participation, Springer, 2011, pp. 25-35.

[23] R. Effing, J. van Hillegersberg, and T. W. Huibers, "Social Media Participation and Local Politics: A Case Study of the Enschede Council in the Netherlands," in Electronic Participation, Springer, 2013, pp. 57-68.

[24] R. Effing, J. van Hillegersberg, and T. Huibers, "Social Media Indicator and Local Elections in the Netherlands: Towards a Framework for Evaluating the Influence of Twitter, YouTube, and Facebook," in Social Media and Local Governments, Springer, 2016, pp. 281-298.

[25] M. Johannessen, "Genres of participation in social networking systems: A study of the 2009 Norwegian parliamentary election," Lecture Notes in Computer Science (including subseries Lecture Notes in Artificial Intelligence and Lecture Notes in Bioinformatics), vol. 6229 LNCS, pp. 104-114, 2010.

[26] M. R. Johannessen, "Genres of Participation in Social Networking Systems: A Study of the 2013 Norwegian Parliamentary Election," in Electronic Participation, Springer, 2014, pp. 26-37.
[27] P. Panagiotopoulos, A. Z. Bigdeli, and S. Sams, "Citizengovernment collaboration on social media: The case of Twitter in the 2011 riots in England," Government Information Quarterly, vol. 31, no. 3, pp. 349 - 357, 2014.

[28] C. Guttormsen and Ø. Sæbø, "Municipalities 'Like' Facebook: The Use of Social Media in Local Municipalities," in Organizational Change and Information Systems, vol. 2, P. Spagnoletti, Ed. Springer Berlin Heidelberg, 2013, pp. 157-166.

[29] Ø. Sæbø, "Understanding Twitter ${ }^{\mathrm{TM}}$ use among parliament representatives: A genre analysis," Lecture Notes in Computer Science (including subseries Lecture Notes in Artificial Intelligence and Lecture Notes in Bioinformatics), vol. 6847 LNCS, pp. 1-12, 2011.

[30] A. Frame and G. Brachotte, "Le tweet stratégique: Use of Twitter as a PR tool by French politicians," Public Relations Review, no. 0, 2015.

[31] M. R. Johannessen and A. Følstad, "Political social media sites as public sphere: A case study of the norwegian labour party," Communications of the Association for Information Systems, vol. 34, no. 1, pp. 1067-1096, 2014.

[32] K. Parisopoulos, E. Tambouris, and K. Tarabanis, "Facebook and Greek Elections: New Fad or Real Transformation?," Technology and Society Magazine, IEEE, vol. 31, no. 3, pp. 58-64, 2012.

[33] R. Sandoval, R. Torres Matus, and R. Nava Rogel, "Twitter in Mexican Politics: Messages to People or Candidates?," 2012.

[34] E. Dalakiouridou, E. Tambouris, and K. Tarabanis, "eParticipation and online social networks: The case of the European Institutions," Eur. J. ePract, 2012.

[35] G. Di Fraia and M. C. Missaglia, "The use of Twitter in 2013 Italian political election," in Social Media in Politics, Springer, 2014, pp. 63-77.

[36] A. O. Larsson and B. Kalsnes, "'Of course we are on Facebook': Use and non-use of social media among Swedish and Norwegian politicians," European Journal of Communication, p. 0267323114531383, 2014.

[37] L. H. Hoffman, "Participation or communication? An explication of political activity in the Internet age," Journal of Information Technology \& Politics, vol. 9, no. 3, pp. 217-233, 2012.

[38] E. Bonsón, L. Torres, S. Royo, and F. Flores, "Local egovernment 2.0: Social media and corporate transparency in municipalities," Government Information Quarterly, vol. 29, no. 2, pp. 123-132, Apr. 2012.

[39] J. Gaventa and C. Valderrama, "Participation, citizenship and local governance," 1999.

[40] I. Mergel, "A framework for interpreting social media interactions in the public sector," Government Information Quarterly, vol. 30, no. 4, pp. 327 - 334, 2013.

[41] A. O. Larsson, "Bringing it all back home? Social media practices by Swedish municipalities," European Journal of Communication, vol. 28, no. 6, pp. 681-695, 2013.

[42] A. Triantafillidou, G. Lappas, P. Yannas, and A. Kleftodimos, "Greek Local E-Government 2.0: Drivers and Outcomes of Social Media Adoption," in Social Media and Local Governments, vol. 15, M. Z. Sobaci, Ed. Springer International Publishing, 2016, pp. 153-170.

[43] A. Macintosh and A. Whyte, "Towards an evaluation framework for eParticipation," Transforming Government: People, Process and Policy, vol. 2, no. 1, pp. 16-30, 2008. 